\title{
Türkiye'de Doğrudan Yabancı Sermaye Yatırımlarının Gelişimi ve Ekonomik Büyümeye Etkisinin Ekonometrik Analizi (1985-2017)
}

\author{
The Development of Foreign Direct Investments (FDI) in Turkey and an Econometric \\ Analysis of Its Effects of Economic Growth (1985-2017)
}

Ali Osman BALKANLI*

$\ddot{O} Z$

Türkiye, geçmişten gelen mirasın sonucu olarak sermaye ve girişim yetersizliğini uzun süre yaşamış bir ekonomidir. Bu durum nedeniyle ülkede yatırımların artırılabilmesi noktasında yabancı sermaye ve dolayısiyla doğrudan yabancı sermaye yatırımlar büyük öneme sahip olmuştur. Dolaylsılla da, bu önemlilik nedeniyle yabancl sermayenin ve doğrudan yabancı sermaye yatırımlarının teşvik edilmesi tüm dönemlerde geçerli bir uygulama olmuştur. Ancak tüm dönemlerde yabancı sermayeye ve doğrudan yabancı sermaye yatırımına olumlu bakllmakla birlikte, Türkiye'ye dönük yabancı sermaye girişlerinin ve de özellikle doğrudan yabancı sermaye yatırımlarının dikkat çekici artışı ancak 1980 sonrasında olmuştur. Bu makalenin konusu, 1980'li yıllardan günümüze dek geçen sürede doğrudan yabancı sermaye yatırımlarının Türkiye'de gelişimi ve bu süreçte doğrudan yabancı sermaye yatırımların ekonomik büyüme üzerine etkisinin incelenmesidir. Bu bağlamda doğrudan yabancı sermaye yatırımlarl ve ekonomik büyüme ilişkisini test edebilmek için eşbütünleşme ve durağanlık testleri yapılmıştır. Ekonometrik araştırmadan elde edilen sonuca göre, Türkiye'de doğrudan yabancı sermaye yatırımlarının uzun dönemde ekonomik büyüme üzerinde olumlu bir etkiye sahip olduğu görülmüştür.

\section{ANAHTAR KELIMELER}

Doğrudan Yabancı Sermaye Yatırımı, Ekonomik Büyüme, Türkiye'de Doğrudan Yabancı Sermaye Yatırımları

\begin{abstract}
Turkey has lived the capital and enterprise inadequacy as a result of a legacy of the past, for long time.Due to this situation, foreign capital and hence foreign (external) investments have been of a great importance in order to increase investments in the country. The encouragement of foreign capital and foreign investments due to this importance is became a valid practice in all periods. However, while the foreign capital and foreign investments is viewed favorably at the all periods, the increase of the foreign investment inflows to Turkey has realized after 1980, not before. The subject of this article is the development of foreign investments in Turkey and the impact of foreign direct investments (FDI) on economic growth for the period of 1980 to 2017. In this context, cointegration and stability analysis were performed to test the relationship between foreign investments and economic growth. According to the results obtained from our econometric research, foreign direct investments in Turkey in the long term has a positive effect on economic growth.
\end{abstract}

\section{KEYWORDS}

Foreign Direct Capital Investment, Economic Growth, Foreign Direct Investements in Turkey

\begin{tabular}{|c|c|c|}
\hline \multicolumn{2}{|r|}{$\begin{array}{c}\text { Makale Geliş Tarihi / Submission Date } \\
\text { 15.02.2019 }\end{array}$} & $\begin{array}{c}\text { Makale Kabul Tarihi / Date of Acceptance } \\
15.03 .2019\end{array}$ \\
\hline Atıf & $\begin{array}{l}\text { Balkanlı, A.O. (2019). Türkiye'de D } \\
\text { Etkisinin Ekonometrik Analizi (1985-2 } \\
\text { 175-186. }\end{array}$ & $\begin{array}{l}\text { aye Yatırımlarının Gelişimi ve Ekonomik Büyümeye } \\
\text { si Sosyal Bilimler Meslek Yüksekokulu Dergisi, } 22 \text { (1), }\end{array}$ \\
\hline
\end{tabular}

\footnotetext{
* Dr.Öğr. Üyesi, İstanbul Üniversitesi, Siyasal Bilgiler Fakültesi, İktisat A.B.D., aobalkan @ yahoo.com, ORCID: 0000-0003-1074-
} 9069 


\section{GİRIŞ}

Kaynak gereksinimi duyan ekonomiler için doğrudan yabancı sermaye yatırımlarında artışların süreğenliğinin apriorik olarak ekonomik büyümenin sürdürülebilmesine de destek olacağı düşünülebilir. Açıktır ki, bir ekonomide tasarrufların yetersizliğinde ya da azlığında yatırım düzeyinin artırılabilmesi ilgili ekonominin milli gelirinin bir üst denge düzeyine taşınmasını destekleyecektir. Özellikle Türkiye'nin genç nüfusu ve istihdam sorunları düşünüldügünde, yatırımların üretimi artıracağ 1 ve üretimin de istihdamı artıracağı varsayımında, doğrudan yabancı yatırımların ekonomide üretim büyümesini destekleyeceği ve dolayısıyla doğrudan yabancı sermaye yatırım artışının istihdama da olumlu etki yapabileceği düşünülebilir. Türkiye 1980 sonrasında ekonomisini dişa açmıştır. Bu dışa açılma sürecinde yabancı sermaye girişlerini teşvik etmek üzere mevzuatını değiştirmiş ve yeni teşvikler getirmiştir. Yaşanan bu değişimin de etkisinde doğrudan yabancı sermaye yatırımlarında yıllar itibariyle artışlar söz konusudur. Makalede ilk bölümde Türkiye'ye giriş yapan yabancı sermayenin 1980 sonrası ve özellikle de 2000'li yıllarda sergilediği gelişmeler incelenecektir. Dış yatırımların sergilediği gelişim trendlerinin ardından, uzun dönemli olarak 1985-2017 döneminde doğrudan yabancı sermaye yatırımları ile ülkenin ekonomik büyümesi arasında nasıl bir ilişki olduğu, kurulan ekonometrik modele göre eşbütünleşme ve durağanlık analizleri ile incelenecektir.

\section{TÜRKIYY'DE DOĞRUDAN YABANCI SERMAYE YATIRIMLARIN GELIŞSIMİ VE YÖNELIŞ̧i}

Genel olarak, yabancı sermayenin konak ülkede olumlu etkiler üreteceği var sayılır. Bu olumlu etkilerden bazıları yabancı sermaye yatırımlarının dışsallıklar yaratması ve teknoloji katkısıyla ilişkilidir (Olokoyo,2012:5). Ancak elbette yabancı sermayeden beklenenler sadece bunlarla sinırlı değildir. Bunun ötesinde dış yatırımların girdikleri konak ekonomilerde üretime, piyasalara ve istihdama katkı sağlayacağı öngörülür. Türkiye'de de yabancı sermaye bu ve benzeri beklentilerin desteğinde teşvike konu olmuştur. Ancak burada belirtmek gerekir ki, bir ekonomiye yabancı sermayenin girişi, esasen üç biçimde gerçekleşir. Yabancı sermaye kendisini birinci olarak doğrudan yabancı sermaye yatırımı (dış yatırım) olarak, ikinci olarak portföy yatırımı olarak, üçüncü olarak da dış borçlanma olarak gösterebilir.

Doğrudan yabancı sermaye yatırımı A ülkesindeki sermaye sahibinin/sermaye grubunun B ülkesinden işletme satın almak ya da var olan bir şirketin sermayesine katılmak ya da doğrudan doğruya bir işletme kurmak yoluyla gerçekleştirdiği yatırımdır. Doğrudan yabancı sermaye yatırımı ile birlikte, ilgili sermaye sahibi/grubu ilgili işletmede sahip ve denetleyici konumuna taşınırken, dolayısıyla da, sahipliğin bir yansıması olarak ilgili işletmeye işletmecilik ve yönetim bilgisi, teknik bilgi ve teknoloji sunabilir (Balkanlı,2017:2). Portföy yatırımı ise diğer ülkelerden gelerek konak ülkede hisse senedi, tahvil, bono gibi sermaye piyasası araçlarına yatırım yapmak etkinliğidir. Dış borçlanma ise A ülkesindeki fon sahiplerince B ülkesinde borç talep eden gruplara ve/veya kamu kurumlarına ve diğer borç talep edicilere faiz v.b. bedeli karşılığ borç verilmesi etkinliğidir. Doğrudan yabancı sermaye yatırımlanı (diğer yabancı sermaye etkinliklerine göre) doğrudan doğruya diğer bir ülkeden bir başka ülkeye ekonomik etkinlik gerçekleştirmek üzere sermaye girişi yapılmasıdır ki, onun bu yönelişi/özelliği dış yatırımları ilgili (giriş yaptığı) ülkede ekonomik faaliyette bulunmada büyük ölçüde "ülkenin kendi sermayesi gibi” olmayı getirdiği için önemli ve özel kılar.

Türkiye, kapitalist üretim tarzına geç girişinin etkisinde ve sermayeye dönüşecek doğal kaynaklarının olmamasının varlığında, uzun dönem itibariyle tarihten gelen bir sermaye yetersizliği ile hep karşı karşıya kalmıştır. Ayrıca Türkiye, 1980 öncesinin koşulları düşünüldügünde, kapitalist üretim tarzının bilinen "girişimci oluşum süreçlerini” yaşamamasının etkisinde, ve toplumsal-siyasal-kültürel yapılarının etkisinde, girişimci sınıfının yetersizliğini yaşayan bir ekonomi olmuştur. 1980 sonrası dünya ekonomisi değişirken, Türkiye'de değişim sürecine girmiş ve bu süreçte, sermaye ve girişim yetersizliğini karşılama ve ülke içinde var olan sermaye ve girişimci sınıfını da geliştirebilme yolunda, yabancı sermayeyi teşvik etmeye yönelmiştir. $\mathrm{Bu}$ teşviklerin ve yapı değişikliğinin ve dünya ekonomisi koşullarının buna imkan vermesinin desteğinde, 1980 sonrasında ülkeye giren yabancı sermaye artış gösterirken, bu sermayenin özel bir biçimi olarak doğrudan yabancı sermaye yatırımlarında da dikkate değer artışlar yaşanmıştır. Bu artış 2000'li yıllarda da artarak sürmüştür.

Türkiye'de 1980'ler öncesinde ve 2000'lere kadar sanayi kesimine yönelişi belirgin olan doğrudan yabanc1 sermaye yatırımlarının, 2000'li yıllarla birlikte büyük ölçüde hizmetler alanında yoğunlaşmaya yöneldiği görülür (www.tuik.gov.tr, web erişim:15.01.2019). Tarım ise tüm dönemlerde çok fazla rağbet görmeyen bir kesim durumundadır. Örneğin, 2000'li yılların verilerin incelenmesinden de görülen odur ki, Türkiye'de tarım sektörüne dönük dış yatırımlar oldukça düşük düzeylerdedir. Örneğin 2006 yılında tarım kesimine dönük 6 milyon dolarlık bir yatırımdan söz ederken, bu miktarın 2018 yılında 29 milyon dolar olduğu görülür. 2018 yılında ülkeye giren doğrudan yabancı yatırım düzeyiyle (5.438 milyon dolar) ilişkilendirildiğinde, (diğer 
yıllarda da benzer durum vardır. Bkz. Ek-Çizelge 2) oldukça düşük bir düzeyi ifade eder. Yabancı yatırımların yatırımı cazip bulduğu hizmetler kesiminde özellikle yöneldiği alanlar ise Finans ve sigorta faaliyetleri başta olmak üzere, Parasal aracı kuruluşlar kesimi, Ulaştırma depolama hizmetleri kesimleri ile Toptan ve perakende ticaret kesimi olmuştur. Dış yatırımların sanayi kesimini 2000'li yıllarda da hala cazip gördüğü görülmektedir. Öyle ki doğrudan yabancı sermaye yatırımlarının hizmetler kesimi sonrasında, ikinci sırada yöneldiği diğer alan sanayi kesimidir. Sanayi kesiminde yoğunlaşılan alan ise imalat sanayiidir ve burada da gıda içecek ve tütün imalatı kesimi ve ana metal sanayi en fazla yönelinen alanlardır.

Diğer taraftan, 2000'li yıllarda Türkiye'ye yönelen doğrudan yabancı sermaye yatırımları ağırlıklı olarak Avrupa ülkeleri kaynaklıdır. Öyle ki, toplam doğrudan yatırımlar içerisinde Avrupa ülkelerinin payı 2005 yılında yüzde 77.9 iken, 20118'de yüzde 65.3'tür. Bu durum 1980 öncesinde de aynıdır (www.tuik.gov.tr, web Erişim:10.01.2019). Avrupa ülkeleri arasında ise Almanya, Avusturya, Hollanda, İngiltere, İspanya ve Lüksemburg ilk sıralarda yer almaktadır. İncelenen dönem içerisinde A.B.D.'nin payı yüksek olmayan bir düzeydir. Bu pay 2005 yılında yüzde 1 iken, 2018 yılında yüzde 6.7'dir. Avrupa bölgesinin peşi sıra gelen doğrudan yatırım kaynak bölgesi Asya olmuştur. Asya bölgesinin toplam doğrudan yabancı sermaye yatırımları içerisindeki payı 2005'de yüzde 20.6 iken, 2018'de yüzde 26.6'dır. Yatırımcı yönelişinde önde olan diğer bir bölge ise Ortadoğu'dur. Ortadoğu kaynaklı doğrudan yatırımların 2005'de payı yüzde 19.7 iken, 2018'de yüzde 15.8 'dir. Bu yıllarda Türkiye'ye yönelen diş yatırımlar içerisinde dikkat çekici bir biçimde Azerbaycan'ın payının arttığı görülmektedir. Öyle ki, 2005 yılında Azerbaycan'dan Türkiye'ye 2 milyon dolar düzeyinde giriş var iken (Toplam doğrudan yabancı sermaye yatırım girişi 6.652 milyon dolardır) , 2018 yılında Azerbaycan kaynaklı dış yatırım payı 503 milyon dolar ile (2017'de bu değer 1.005 milyon dolardır) yüzde 9.3'tür (Bkz.Ek-Çizelge 3). Doğrudan yabancı sermaye yatırımlarında dikkati çeken diğere bir durum da, 2016 yılı ile birlikte doğrudan yabancı sermaye yatırımlarının miktarında yaşanan azalmadır. 2015 yılında 12.077 milyon dolar olan doğrudan yabancı sermaye yatırım düzeyi, 2016 ve 2017 'de düşüş göstermiş ve 2018 yılında da 5.438 milyar dolara düşmüştür (Bkz. Ek-Çizelge 1).

\section{DOĞRUDAN YABANCI SERMAYE YATIRIMLARI-EKONOMİK BÜYÜME İLISSKISSINE DAIIR LITERATÜR TARAMASI}

Literatürde dış yatırımlar ile ekonomik büyüme üzerinde farklı ekonometrik modellere göre farklı sonuçlar alındığı görülmektedir. Ayrıca ülke koşullarının farklı olması da sonuçlardaki bu farklılaşmayı getirmiştir. Örneğin, Usha Nair-Reichert and Diana Weinhold, 2001 yılında gerçekleştirdikleri "Causality Tests For CrossCountry Panels: A New Look at FDI and Economic Growth in Developing Countries" adlı çalışmada, doğrudan yabancı sermaye yatırımları ile ekonomik büyüme arasındaki dinamik ilişkiyi analiz etmek için doğrudan yabancı sermaye yatırımı ve ekonomik büyüme üzerine teorik ve ampirik literatürün de desteğinde, 1971'den 1995'e kadar 24 gelişmekte olan ülkeyi incelemişler ve bu değişkenler (dış yatırım-ekonomik büyüme) arasındaki nedensel ilişkinin ülkeler arasında oldukça heterojen olabileceğini güçlü kanıtlarla göstermişlerdir (U. Nair-Reichert and D.Weinhold,2001).

Türkiye için doğrudan yabancı sermaye yatırımları ve ekonomik büyüme ilişkisinin saptanması noktasında F.T. Koyuncu 2017 yılında yayınladığı araştırmasında (Doğrudan Yabanc1 Yatırımlar, Ekonomik Büyüme ve İstihdam Arasındaki İlişki: Türkiye Uygulaması (1990-2015)), 1990-2015 döneminde Türkiye'de doğrudan yabancı yatırımlar, ekonomik büyüme ve istihdam arasındaki ilişkinin varlığı ve yönünü Granger nedensellik analizi ile test ederek incelemiştir. Koyuncu, araştırmasının sonucunda, doğrudan yabancı yatırımlardan ekonomik büyümeye doğru uzun dönemli bir ilişki saptamıştır (Koyuncu,2017). M. Acar ise 2016 yılında yayınladığı "Doğrudan Yabancı Sermayenin Ekonomik Büyümeye Etkisi: Türkiye Örneği” adlı araştırmasında, Türkiye'ye ilişkin olarak 2001-2015 yılları için nedensellik analizi ile bir araştırma gerçekleştirmiştir. Acar tarafından yapılan bu çalışmaya göre, doğrudan yabancı sermaye yatırımları ve ekonomik büyüme arasında bir nedensellik ilişkisi bulunamamıştır (Acar,2016).

Alagöz, Erdoğan ve Topallı 2008'de yayınladıkları "Doğrudan Yabancı Sermaye Yatırımları ve Ekonomik Büyüme: Türkiye Deneyimi 1992-2007" adlı makalede gerçekleştirdikleri regresyon analizinde, 1992-2007 dönemi için doğrudan yabancı sermaye yatırımları ve ekonomik büyüme arasında nedensellik ilişkisi bulamamışlardır. Ayrıca çalışmada özgül olarak 2002-2007 dönemini de ayırarak incelenmişlerdir. Burada kurdukları modelin esneklik katsayılarına göre ise doğrudan yabancı sermaye yatırımlarının ekonomik büyüme üzerindeki etkisinin orta şiddette olduğunu saptamışlardır (Alagöz, Erdoğan ve Topallı 2008).

A. Ekinci ise 2011'de gerçekleştirdiği bir çalışmada (Doğrudan Yabancı Yatırımların Ekonomik Büyüme ve İstihdama Etkisi: Türkiye Uygulaması (1980-2010)) doğrudan yabancı yatırımlar ile ekonomik büyüme ve istihdam arasında uzun dönemli ilişki olup olmadığını belirlemek için 1980-2010 dönemine ilişkin verileri kullanarak, söz konusu değişkenler arasındaki ilişkiyi Granger nedensellik analizi ile test etmiştir. Sonuç 
olarak, Ekinci doğrudan yabancı yatırımlar ile ekonomik büyüme arasında uzun dönemli bir ilişki saptarken, doğrudan yatırımlar ile istihdam arasında ise bir ilişki bulamamıştır. Doğrudan yatırımlar ile ekonomik büyüme arasında bulunan nedensellik ilişkisinin ise çift yönlü bir ilişki biçiminde olduğunu saptamıştır (Ekinci,2011).

Ağayev ise 2010'da yayınlanan bir çalışmasında 1994-2008 döneminde, doğrudan yatırımlar ekonomik büyüme ilişkisini 25 geçiş ekonomisine ait panel eşbütünleşme ve panel nedensellik analizlerini kullanarak incelemiştir. Ağayev'in gerçekleştirdiği çalışmada, 25 geçiş ekonomisi için uygulanan panel eşbütünleşme ve nedensellik analizlerinin sonuçları dış yatırım-büyüme ilişkisini desteklemektedir. Şöyle ki: Pedroni panel eşbütünleşme analizi sonuçlarına göre doğrudan yatırımlar ve ekonomik büyüme değişkenleri uzun dönemde birlikte hareket etmektedirler. Panel EKK, sabit etkiler ve rastsal etkiler modellerine dayanan geleneksel Granger nedensellik, Holtz-Eakin ve diğerleri (1988) tarafindan önerilen ve iki aşamalı EKK yöntemine dayanan panel nedensellik sınaması sonuçları ise doğrudan yabancı sermaye yatırımlarından ekonomik büyümeye doğru güçlü, tersi yönde ise daha zayıf bir nedensellik ilişkisinin olduğunu göstermektedir (Ağayev,2010).

Ayaydın "Doğrudan Yabancı Yatırımlar ile Ekonomik Büyüme Arasındaki İlişkinin İncelenmesi: Türkiye Örneği” (2010) adlı çalışmasında, 1970-2007 dönemi Türkiye'yi, E-views 5.0, Rats ve SPSS paket programları (ve birim kök analizi, Johansen-Juselius Ko-entegration testi ile VAR nedensellik analizi ve varyans ayrıştırmasından oluşan VAR analizi yöntemleri) kullanarak incelemiş ve buna göre VAR nedensellik analizi, varyans ayrıştırmasıyla dış yatırımlardan GSMH'ye doğru tek yönlü bir nedensellik ilişkisi saptanmıştır. Türkiye'de doğrudan yabancı sermaye yatırımları ile ekonomik büyüme arasında pozitif güçlü bir ilişki tespit edilmiştir (Ayaydın, 2010).

Uğurlu ise 2010 y1lında "Growth and Openness Relatıonshıp in The EU-15: Panel Data Analysis" adlı çalışmasında 15'li Avrupa Birliği grubu ülkeleri için dışa açıklık ekonomik büyüme ilişkisine dair 1996-2003 dönemi için panel data ve zaman serileri analizi ile test gerçekleştirmiş ve burada dışa açıklığın ekonomik büyümeyi zayıf ve negatif etkilediğini saptarken, genel olarak yatırımların ekonomik büyümeyi olumlu etkilediğini saptamıştır (Uğurlu, 2010).

Simionescu, 2016'da gerçekleştirdiği çalışmada, 2008-2014 döneminde AB-28 grup ülkelerinde reel GSYH oranı ve doğrudan yabancı sermaye yatırımları ilişkisini incelemiştir. Burada panel verileriyle yapılan Granger nedensellik testinden görülmüştür ki, GSYH ile doğrudan yabancı sermaye yatırımları arasında \% 5 anlamlılık düzeyinde iki yönlü bir nedensel ilişki vardır (Simionescu, 2016). Alfaro, Chanda, Kalemli-Ozcan ve Sayek ise 2000'de 1981-1992 dönemi 39 ülke için, 1977-1992 dönemi 41 ülke için yaptıkları ortak çalışmada saptamaları odur ki, dış yatırım ile büyüme arasındaki bağlantı nedenseldir ve dış yatırımlar finansal piyasalar üzerinden büyümeyi destekler (Alfaro, Chanda, Kalemli-Ozcan ve Sayek,2000).

Viral Pandya ve Sommala Sisombat, 2017'de yayınladıkları bir çalışmada, dış yatırım girişlerini ve bunun Avustralya'daki ekonomik büyüme üzerindeki etkisini incelemişlerdir. Pandya ve Sisombat, makalede regresyon analizi ile dış yatırım ile Avustralya'nın ekonomik büyümesi arasındaki ilişkiyi incelemişler ve sonuçta, doğrudan yabancı yatırım girişlerinin, GSYİH'da büyüme, ihracat performansı ve istihdam dahil olmak üzere Avustralya ekonomisine katkıda bulunduğunu saptamışlardır (Viral Pandya ve Sommala Sisombat, 2017)

Mohammad Amin, Almfrajiab Mahmoud ve Khalid Almsafir, 2013 yılında yayınladıkları bir makalede, 1994'den 2012'ye kadar geçen sürede dış yatırımlar ile ekonomik büyüme arasındaki ilişkiyi test eden araştırmaları incelemiş̧lerdir. Bu inceleme sonucunda, dış yatırım-ekonomik büyüme ilişkisinin anlamlı derecede olumlu olduğunu, ancak bazı durumlarda negatif olduğunu saptamışlardır. Bu iki değişken arasındaki ilişkinin farklı bulunmasında faktörler ise insan sermayesinin yeterli düzeylerde olup olmaması, finansal piyasaların gelişmişliği, yerli ve yabancı yatırımlar arasındaki tamamlayıcılık ve ticaret rejimlerinin açıklık düzeyleri olarak görülmüştür (Mohammad Amin, Almfrajiab Mahmoud ve Khalid Almsafir, 2013).

Ünsal ise 2017 yılında yayınladığı çalışmada, doğrudan yatırımların Türkiye ve diğer OECD ülkelerinde ekonomik büyüme üzerindeki etkilerini Türkiye ekonomisi için bir zaman serisi analizi yaparak ve OECD ülkeleri için bir panel veri analizi yaparak karşılaştırmalı olarak incelemiş ve çalışma sonuçlarına göre, Türkiye ekonomisindeki doğrudan yabancı yatırımlarla ekonomik büyüme arasında uzun vadeli veya kısa vadeli bir ilişki bulamamıştır. Driscoll-Kraay Standart Hatalarıyla Sabit Etkiler Regresyonu sonuçlarına göre ise doğrudan yabancı sermaye yatırımlarının OECD ülkelerinde ekonomik büyümeyi olumlu yönde etkilediği görülmüsstür (Ünsal,2017).

Zandile and Phiri ise 2018'de 1970-2017 dönemi verilerini kullanarak eşbütünleşme analizini kullanarak Burkino-Faso'yu incelemişlerdir. Çalışma sonucunda, saptanan odur ki, doğrudan yabancı sermaye yatırımları 
ihracata olumlu etki yaparken, kısa vadede ekonomik büyüme üzerinde doğrudan veya dolaylı bir etki yapmamaktadır (Zandile and Phiri,2018).

Iamsiraroja ve Ulubaşoğlu tarafından 2015 yılında yapılan bir çalışmada ise inceleme öbeği olarak, 19702009 yılları arası 140 ülke kullanılmıştır. Bu araştırma sonucunda, doğrudan yabancı sermaye yatırımlarının ekonomik büyümeyi olumlu yönde etkilediği ve bu durumun gelişmekte olan ekonomilerde daha belirgin olduğu görülmüştür. Yine aynı çalışmada doğrudan yabancı sermaye yatırımı-ekonomik büyüme ilişkisinde, pozitif büyüme için uygun emme kapasitesi göstergelerinin ticarete açıklık ve finansal gelişme olduğu belirtilmiştir (Iamsiraroja ve Ulubaşoğlu, 2015). Carbonell ve Werner ise 2018'de yayınladıkları araştırmalarında, 1984-2010 döneminde İspanya'yı incelemişler ve İspanya'da doğrudan yabancı sermaye yatırımlarının ekonomik büyümeyi teşvik ettiğine dair olumlu bir kanıt bulamamışlardır (Carbonell ve Werner,2018).

S. Yao ise 2006'da yaptığı çalışmada 1978-2000 döneminde 28 Çin kentini kapsayan geniş bir panel veri seti kullanarak, ihracatın ve doğrudan yabancı sermaye yatırımlarının ekonomik performans üzerindeki etkisini incelemiştir. Pedroni'nin panel birim kök testini ve Arellano ve Bond'un dinamik panel veri tahmin tekniğini benimseyen bu araştırma, hem ihracatın hem de doğrudan yabancı sermaye yatırımlarının ekonomik büyüme üzerinde güçlü ve olumlu bir etkiye sahip olduğunu göstermiştir (Yao,2006).

\section{AMPRİK ÇALIŞMA: YÖNTEM VE VERİ SETİ}

Doğrudan Yabancı Sermaye Yatırımları (FDI/D.Y.S.Y.) ile Gayri Safi Yurtiçi Hâsıla (GDP/GSYIH) arasında nedensellik ilişkisi E-views $10+$ programı kullanılarak araştırılmıştır. Tüm veriler A.B.D. doları bazındadır ve FDI ve GSYİH değişkenlerini içerir. Zaman serisi 1985-2017 yıllarını kapsamaktadır. Veriler Dünya bankası veri tabanından derlenmiştir. Araştırmada eşbütünleşme (Koentegrasyon) ve durağanlık analizi kullanılmıştır. Eşbütünleşme analizi zaman serisinin yapısında bozulmaların olabildiği durumlarda daha fazla açıklayıcıdır (Sümer,2013a:268). Serilerin durağanlığını anlayabilmede birim kök sınaması oldukça yararlı bir test olup, bu noktada Dickey-Fuller (ADF) testi ile bütün değişkenlerin durağanlık analizleri yapılmıştır. İki değişkene ait zaman serilerine ilişkin bir regresyon denklemi tahmin edildiğinde bu regresyon denkleminin gerçekliğini saptayabilmede, en iyi analiz ögesi eşbütünleşme testidir (Sümer, 2013b:278). Bu nedenle de burada eşbütünleşme analizi kullanılmıştır.

\begin{tabular}{|l|l|}
\hline \multicolumn{1}{|c|}{ Model } & GDP $=\beta 0+\beta 1 . F D I$ \\
\hline GDP=GSYİ. & Gayri Safi Yurt İçi Hasıla \\
\hline FDI: DYSY & $\begin{array}{l}\text { Doğrudan Yabancı Sermaye Yatııımı, Dış } \\
\text { Yatırım }\end{array}$ \\
\hline Veriler: & Dünya Bankası Veri tabanı \\
\hline
\end{tabular}

Boş Hipotez: GDP birim kök içerir

(Null Hypothesis: GDP has a unit root), Exogenous: None,

Gecikme Uzunluğu: 0 (SIC), (Automatic - based on SIC, maxlag=9)

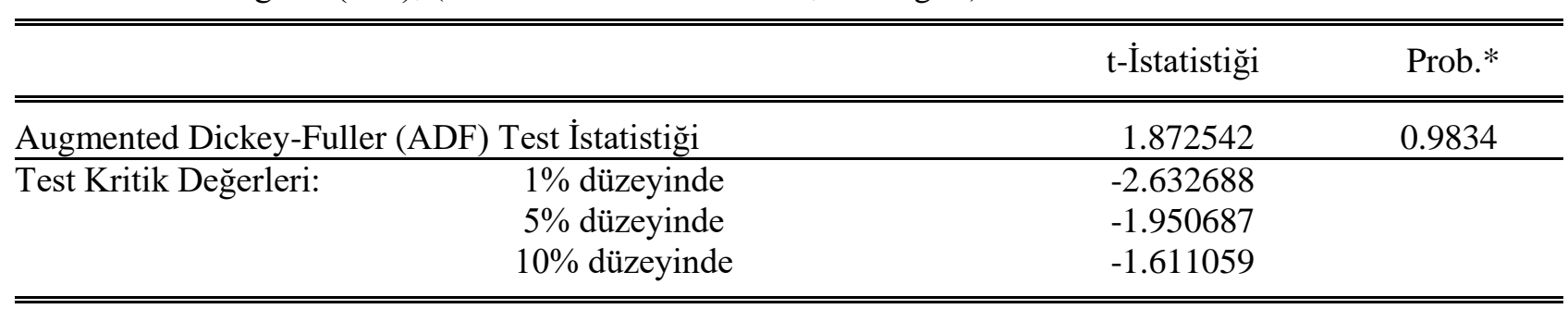

ADF testi, Level (Seviyede) Durağan Değil 
*MacKinnon (1996) tek yönlü p-değerleri

Boş Hipotez: D(GDP) birim kök içerir.

Gecikme Uzunluğu: 0 (SIC), (Automatic - based on SIC, maxlag=9)

\begin{tabular}{|c|c|c|c|}
\hline & & t-İstatistiği & Prob.* \\
\hline \multicolumn{2}{|c|}{ Augmented Dickey-Fuller (ADF) Test İstatistiği } & -4.788378 & 0.0000 \\
\hline Test Kritik Değerleri: & $\begin{array}{l}1 \% \text { düzeyinde } \\
5 \% \text { düzeyinde } \\
10 \% \text { düzeyinde }\end{array}$ & $\begin{array}{l}-2.634731 \\
-1.951000 \\
-1.610907\end{array}$ & \\
\hline
\end{tabular}

1. Mertebeden Durağan.

*MacKinnon (1996) tek yönlü p-değerleri

Boş Hipotez: FDI birim kök içerir.

Gecikme Uzunluğu: 0 (Automatic - based on SIC, maxlag=8)

\begin{tabular}{|c|c|c|c|}
\hline & & t-İstatistiği & Prob.* \\
\hline \multicolumn{2}{|c|}{ Augmented Dickey-Fuller (ADF) Test İstatistiği } & -0.765713 & 0.3768 \\
\hline Test Kritik Değerleri: & $\begin{array}{l}1 \% \text { düzeyinde } \\
5 \% \text { düzeyinde } \\
10 \% \text { düzeyinde }\end{array}$ & $\begin{array}{l}-2.636901 \\
-1.951332 \\
-1.610747\end{array}$ & \\
\hline
\end{tabular}

ADF testi, Level (Seviyede) Durağan Değil

*MacKinnon (1996) tek yönlü p-değerleri

Boş Hipotez: D(FDI) birim kök içerir.

Gecikme Uzunluğu: 0 (Automatic - based on SIC, maxlag=8)

\begin{tabular}{lccc}
\hline \hline & & t-İstatistiği & Prob.* \\
\hline \hline Augmented Dickey-Fuller (ADF) & Test İstatistiği & -4.493266 & 0.0001 \\
\hline Test Kritik Değerleri: & 1\% düzeyinde & -2.639210 & \\
& $5 \%$ düzeyinde & -1.951687 & \\
$10 \%$ düzeyinde & -1.610579 & \\
\hline \hline
\end{tabular}

1. Mertebeden Durağan.

*MacKinnon (1996) tek yönlü p-değerleri. 
Boş Hipotez: (R1 birim kök içerir. Ho, (Null Hypothesis)

Burada R1 gecikmeli hata terimleridir. Aynı mertebeden durağan olan serilerle kurulan modelde hata terimleri, kısa dönem uzun dönem arasında, bir gecikmeli olarak hata düzeltme mekanizması geçiș parametresi olarak kullanılır. Bu parametrenin anlamlı olması ve aynı zamanda bir gecikmelisinin hata düzeltme olarak kullanılması modelin selahiyetini daha da artırmaktadır.

Gecikme Uzunluğu: 0 (Automatic - based on SIC, maxlag=8)

\begin{tabular}{llcc}
\hline \hline & & t-İstatistiği & Prob.* \\
\hline \hline Augmented Dickey-Fuller (ADF) Test İstatistiği & & -2.345297 & 0.0205 \\
\hline Test Kritik Değerleri: & 1\% düzeyinde & -2.636901 & \\
& 5\% düzeyinde & -1.951332 & \\
& 10\% düzeyinde & -1.610747 & \\
\hline \hline
\end{tabular}

Hata terimleri Level (Seviyede) Durağan.

*MacKinnon (1996) tek yönlü p-değerleri.

Eşbütünleşme (Koentegre) uzun dönem ilişkisi nihai modelde net olarak görülmektedir.

Bağımlı Değişken: GDP

Method: Least Squares

Date: 02/07/19 Time: 13:52

Sample (adjusted): 19852017

Included observations: 33 after adjustments

\begin{tabular}{lrlrr}
\hline \hline \multicolumn{1}{r}{ Değişken } & Katsay1 & Std. Hata & t-İstatistiği & Prob. \\
\hline \multicolumn{1}{c}{ C } & $1.97 \mathrm{E}+11$ & $2.79 \mathrm{E}+10$ & 7.062149 & 0.0000 \\
\multicolumn{1}{c}{ FDI } & 35879085 & 2924840. & 12.26702 & 0.0000 \\
\multicolumn{1}{c}{} & 0.686006 & 0.144054 & 4.762153 & 0.0000 \\
\hline \hline R-squared & 0.862603 & Mean dependent var & & $4.17 \mathrm{E}+11$ \\
Adjusted R-squared & 0.853444 & S.D. dependent var & & $3.13 \mathrm{E}+11$ \\
S.E. of regression & $1.20 \mathrm{E}+11$ & Akaike info criterion & & 53.94174 \\
Sum squared resid & $4.30 \mathrm{E}+23$ & Schwarz criterion & & 54.07779 \\
Log likelihood & -887.0388 & Hannan-Quinn criter. & & 53.98752 \\
F-statistic & 94.17295 & Durbin-Watson stat & & 1.519105 \\
Prob(F-statistic) & 0.000000 & & \\
\hline \hline
\end{tabular}

*MacKinnon (1996) tek yönlü p-değerleri

Tahmin Edilen Denklem:

$\mathrm{GDP}=\mathrm{C}(1)+\mathrm{C}(2) * \mathrm{FDI}+\mathrm{C}(3) * \mathrm{R} 1(-1)$

İkame Katsayısı:

$\mathrm{GDP}=197138737588+35879084.5397 * \mathrm{FDI}+0.686006370648 * \mathrm{R} 1(-1)$ 
GSYİH $\rightarrow$ 1.mertebeden durağan ; FDI $\rightarrow 1$.mertebeden durağan.

Dış yatırımlar ile GSiYH arasında eşbütünleşik ilişkiden söz etmek mümkündür. Hata terimlerinin durağanlığına bakıldığında, Level (seviye) durağan olup, GSYİH-FDI arasında 0,68 oranında bir eşbütünleşik uzun dönem ilişkisi söz konusudur.

\section{Grafik 1: GSYİH Büyüme Artışı ve D.Y.S.Yatırımları Zaman-Yatırım Trendi (1985-2017)}

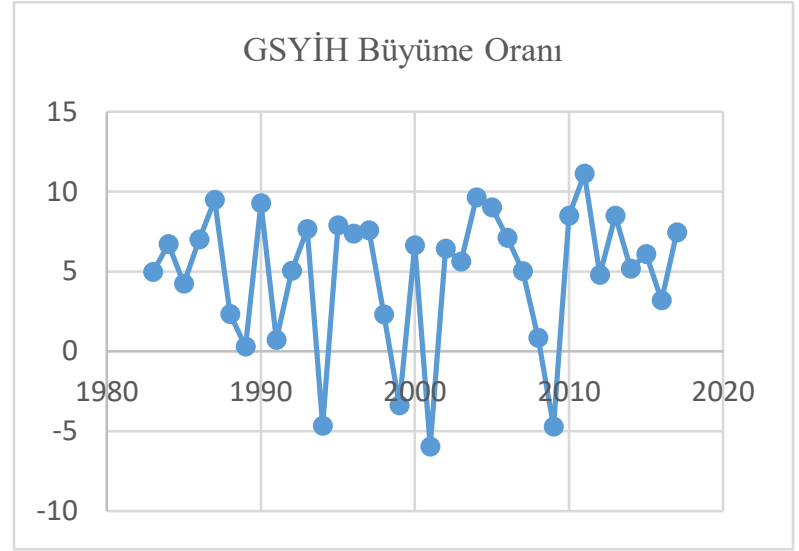

D.Y.S.Yatırımları: Zaman-Yatırım Trendi

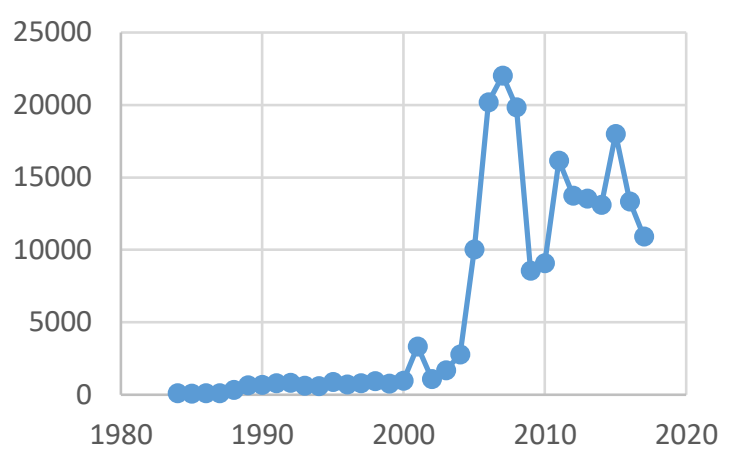

Grafik 2: Aktüel, Kalıcı ve Uyumlanmış Trend Çizgileri

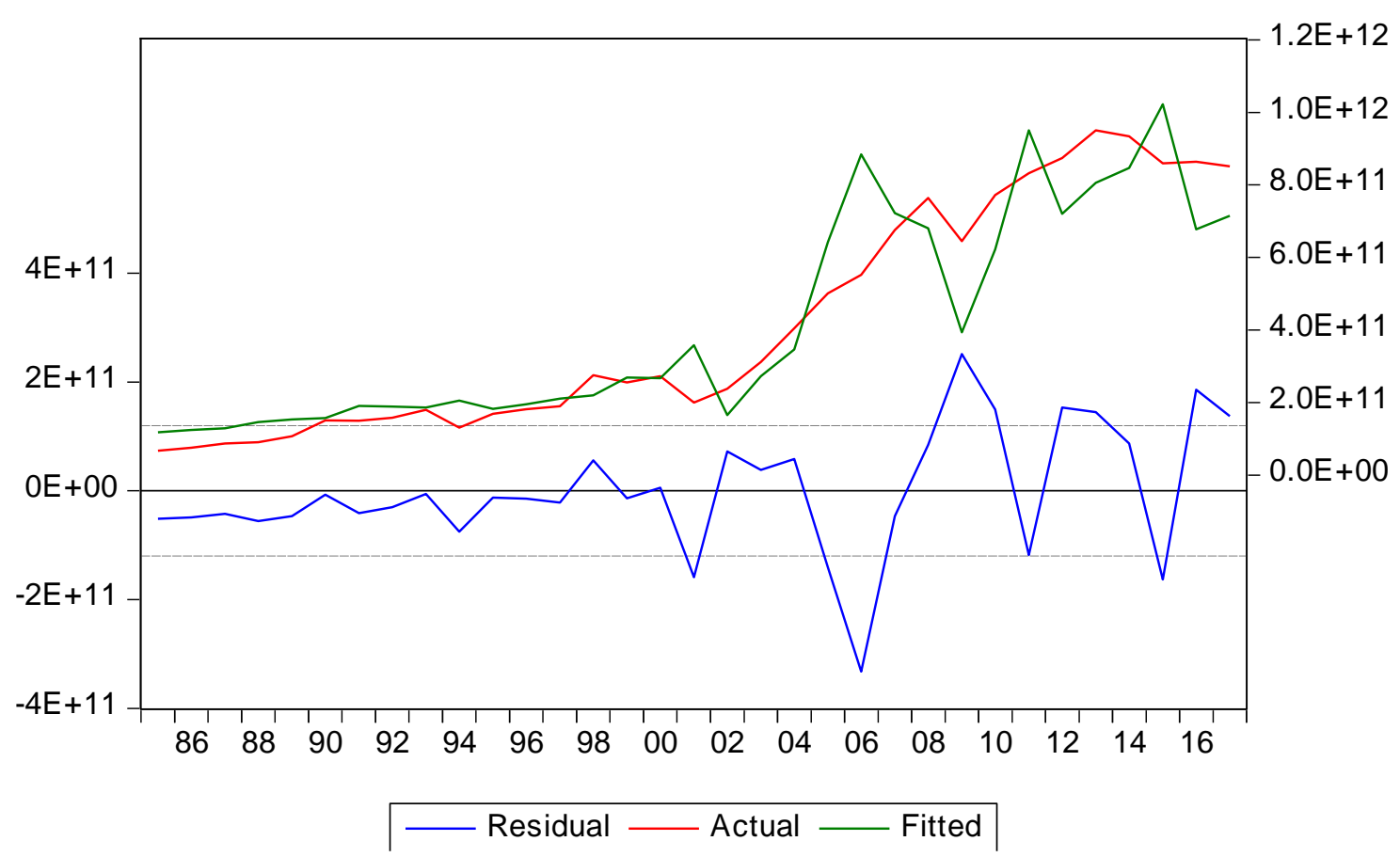




\section{SONUÇ}

Türkiye 1980'li yıllar sonrasında, özellikle 2000'li yıllarda daha büyük tandansta olmak üzere, artan ölçüde doğrudan yabancı sermaye yatırımı çekmeye başlamıştır. Doğrudan yabancı sermaye yatırımlarının dikkate değer artış gösterdiği 2000'li yıllarda doğrudan yabancı sermaye yatırımlarının daha fazla yöneldiği alanlar ise öncelikle hizmetler kesimi ve bunun ardından da imalat sanayi kesimi olmuştur. Hizmetler kesimine yöneliş diğerlerine göre oldukça yüksek düzeylerdedir ve burada da finans-sigorta kesimleri ön plandadır.

1985 yılından 2017 yılına dek geçen sürede, doğrudan yabancı sermaye yatırımlarında artış sürerken, artan yabancı sermaye yatırımlarının ekonomik büyümeyi net bir biçimde olumlu etkilediğini belirtmek gerekir. Eşbütünleşme ve durağanlık analizlerinin gösterdiği odur ki, doğrudan yabancı sermaye yatırımları ile ekonomik büyüme arasında uzun dönemde (1985-2017 döneminde) 0.68 oranında olumlu bir ilişki saptanmıştır. Buradan çıkarsama, yapılarak denilebilir ki, Türkiye'nin teşvikleri kullanarak, istikrarlı politikalar izleyerek doğrudan yabancı sermaye yatırımlarını kendine çekmeyi sürdürebilmesi, ülkenin ekonomik büyümesi üzerinde de olumlu etki yapacaktır. 


\section{KAYNAKÇA:}

Acar,M., (2016), "Doğrudan Yabancı Sermayenin Ekonomik Büyümeye Etkisi: Türkiye Örneği “, Kastamonu Üniversitesi İktisadi ve İdari Bilimler Fakültesi Dergisi Temmuz, Sayi:13,(92-105).

Ayaydın ,H., (2010 ),“Doğrudan Yabancı Yatırımlar ile Ekonomik Büyüme Arasındaki İlişkinin İncelenmesi: Türkiye Örneği”, Dumlupınar Üniversitesi, Sosyal Bilimler Dergisi, (Nisan), Sayı:26.

Ağayev, S., (2010), "Doğrudan Yabancı Sermaye Yatırımları Ve Ekonomik Büyüme İlişkisi: Geçiş Ekonomileri Örneğinde Panel Eştümleşme Ve Panel Nedensellik Analizleri Gazi Üniversitesi İktisadi ve İdari Bilimler Fakültesi Dergisi 12/1, (159-184).

Alagöz;M. , Erdoğan,S. ve Topallı, N., (2008), "Doğrudan Yabancı Sermaye Yatırımları ve Ekonomik Büyüme: Türkiye Deneyimi 1992-2007”, Gaziantep Üniversitesi, Sosyal Bilimler Dergisi, Vol:7/1, (79-89) .

Alfaro, L., Chanda,A., ve Sayek,S., ( 2000), "FDI and Economic Growth: The Role of Local Financial Markets",, https://s3.amazonaws.com/academia.edu.documents/ 30206053/ fdipaper25 .pdf?AWSAccess KeyId= AKIAIWOWYYGZ2Y53UL3A\&Expires=1549787533\&Signature $=0 i S N o e I o V v E k 3 C 3 \mathrm{kxbi2B} \% 2 F A 0 u U E \% 3 \mathrm{D}$ \&response-content-disposition=inline $\% 3 \mathrm{~B} \% 20$ filename\%3 DFDI_and_economic_growth_the_role_of_loca.pdf

Almfrajia, M.A. ve Almsafirc, M.H., "Foreign Direct Investment and Economic Growth Literature Review from 1994 to 2012", International Conference on Innovation, Management and Technology Research, Malaysia, 22 - 23 September, 2013, https://ac.els-cdn.com/ S187704281402850X/1-s2.0-S187704281402850X-main. pdf?tid=88706e61-c24d-42a0-af02-40fe535e6473\&acdnat $=\quad 1549786 \quad 437 \_9 \quad$ 83d97f1e $\quad$ 0f81f2 a881aae17b5177a12.

Balkanl,A.O.,(2017), "The Effects Of Direct Foreign Capital Investments On Economic Growth, Employment And Balance Of Payments", Eurasian Academy of Sciences

Eurasian Business \& Economics Journal ,Volume:10 (1-14).

Carbonell, J.B. ve Werner, R., (2018), "Does Foreign Direct Investment Generate Economic Growth? A New Empirical Approach Applied to Spain", Journal Economic Geography", Volume 94, 2018, (Issue 4).

Ekinci ,A., (2011), "Doğrudan Yabancı Yatırımların Ekonomik Büyüme ve İstihdama Etkisi: Türkiye Uygulaması (1980-2010)”, Eskişehir Osmangazi Üniversitesi IİBF Dergisi,( Ekim), Cilt: 6/2, (71-96) .

Iamsiraroja,S. ve Ulubaşoğlu, M.A., (2015),“ Foreign Direct İnvestment And Economic Growth: A Real Relationship Or Wishful Thinking?”, Economic Modelling, Volume 51,(December), (200-213). https://doi.org/10.1016/j.econmod.2015.08.009 . https://www.sciencedirect. com/science/ article/ pii/S0264999315002138?via\%3Dihub.

Koyuncu ,F.T., (2017), "Doğrudan Yabancı Yatırımlar, Ekonomik Büyüme ve İstihdam Arasındaki İlişki: Türkiye Uygulaması (1990-2015)", Uluslararası Sosyal ve Ekonomik Bilimler Dergisi, Vol:7/2, (62-69).

Nair-Reichert, U. ve Weinhold,D., (2001), "Causality Tests For Cross-Country Panels: A New Look At FDI And Economic Growth İn Developing Countriesy, Oxford Bulletın Of Economıcs And Statıstıcs, 63, 2, (153-171). https://s3.amazonaws.com/academia.edu. documents/41783172/nair-reichert_weinhold_ fdi_and_ economic_growth_ OBES_2001.pdf? AWSAccessKeyId=AKIAIW OWYYGZ2Y53UL3A\& Expires= $1549787537 \&$ Signature $=z Z 0$ pgy $\% 2 F H J U v e b X u V 3 u p L I j O 8 o K A \% 3 D \&$ response-content-disposition=inline $\%$ 3B\% 20 filename\%3DCausality_Tests_for_Cross-Country_Panels.pdf

Olokoyo, F. O., (2012), "Foreign Direct Investment And Economic Growth: A Case Of Nigerı", Bvimsr's Journal Of Management Research, Vol. 4, No 1, April,(1-30).

- Pandya,V. ve Sisombat, S.,(2017), "Impacts of Foreign Direct Investment on Economic Growth: Empirical Evidence from Australian Economy", "International Journal of Economics and Finance, Vol. 9, No. 5., (PDF), https://www.researchgate.net/publication/

316358173_Impacts_of_Foreign_Direct_Investment_on_Economic_Growth_Empirical_Evidence_from_Austral ian_Economy.

Simionescu, M., (2016), "The Relation Between Economic Growth And Foreign Direct İnvestment During The Economic Crisis in The European Union", Zb. rad. Ekon. fak. Rij.,Vol. 34,no. 1, (187-213) 187 doi: 10.18045/ zbefri.2016.1.187.

Sümer, K.K.,(2013a), "Makro Ekonomik Modeller”, Beşir Yay. (İstanbul).

Sümer, K.K.,(2013b), ” Ekonometriye Giriş”, Beşir Yay. (İstanbul).

Uğurlu,E., (2010), "Growth And Openness Relatıonshıp In The Eu-15: Panel Data Analysıs", Ekonomika 2010 Vol. 89/2, (44-54).

Ünsal,M.E., (2017), "FDI and Economic Growth: Comparative Analyses between Turkey and the other OECD Countries", Journal of Current Researches on Business and Economics, Vol:7/2.

www.tuik.gov.tr

Yao, Shujie, (2006), "On Economic Growth, FDI And Exports İn China, Journal Applied Economics", https://www.tandfonline.com/doi/ abs/ 10.1080/00036840500368730, Vol.38, 2006 - Issue 3, (339-351).

Zandile, Zezethu and Phiri, Andrew (2018), "FDI As A Contributing Factor To Economic Growth İn Burkina Faso: How True İs This",https://mpra.ub.uni-muenchen.de/87282/1/MPRA_paper_87282.pdf. 


\section{EKLER}

Ek-Çizelge 1: Türkiye'de 1985-2017 Döneminde GSYİH ve Doğrudan Yabancı Sermaye Yatırımlarının Gelişimi (Milyon ABD Doları ve \% Olarak).

\begin{tabular}{|c|c|c|c|}
\hline Yillar & GSYİH & GSYİH Büyüme Oranı & D1ş Yatırım \\
\hline 1983 & $6,17 \mathrm{E}+10$ & 4,971081 & - \\
\hline 1984 & $6 \mathrm{E}+10$ & 6,712016 & 113,00 \\
\hline 1985 & $6,72 \mathrm{E}+10$ & 4,241336 & 99,00 \\
\hline 1986 & $7,57 \mathrm{E}+10$ & 7,012031 & 125,00 \\
\hline 1987 & $8,72 \mathrm{E}+10$ & 9,485539 & 115,00 \\
\hline 1988 & $9,09 \mathrm{E}+10$ & 2,320737 & 354,00 \\
\hline 1989 & $1,07 \mathrm{E}+11$ & 0,290244 & 663,00 \\
\hline 1990 & $1,51 \mathrm{E}+11$ & 9,266147 & 684,00 \\
\hline 1991 & $1,5 \mathrm{E}+11$ & 0,720279 & 810,00 \\
\hline 1992 & $1,58 \mathrm{E}+11$ & 5,035635 & 844,00 \\
\hline 1993 & $1,8 \mathrm{E}+11$ & 7,651265 & 636,00 \\
\hline 1994 & $1,31 \mathrm{E}+11$ & $-4,66815$ & 608,00 \\
\hline 1995 & $1,69 \mathrm{E}+11$ & 7,878267 & 885,00 \\
\hline 1996 & $1,81 \mathrm{E}+11$ & 7,379664 & 722,00 \\
\hline 1997 & $1,9 \mathrm{E}+11$ & 7,577664 & 805,00 \\
\hline 1998 & $2,76 \mathrm{E}+11$ & 2,308146 & 940,00 \\
\hline 1999 & $2,56 \mathrm{E}+11$ & $-3,38928$ & 783,00 \\
\hline 2000 & $2,73 \mathrm{E}+11$ & 6,640147 & 982,00 \\
\hline 2001 & $2 \mathrm{E}+11$ & $-5,96233$ & $3.352,00$ \\
\hline 2002 & $2,38 \mathrm{E}+11$ & 6,430189 & $1.082,00$ \\
\hline 2003 & $3,12 \mathrm{E}+11$ & 5,608342 & $1.702,00$ \\
\hline 2004 & $4,05 \mathrm{E}+11$ & 9,644246 & $2.785,00$ \\
\hline 2005 & $5,01 \mathrm{E}+11$ & 9,009901 & $10.031,00$ \\
\hline 2006 & $5,52 \mathrm{E}+11$ & 7,109756 & $20.185,00$ \\
\hline 2007 & $6,76 \mathrm{E}+11$ & 5,030441 & $22.047,00$ \\
\hline 2008 & $7,64 \mathrm{E}+11$ & 0,845219 & $19.851,00$ \\
\hline 2009 & $6,45 \mathrm{E}+11$ & $-4,70445$ & $8.585,00$ \\
\hline 2010 & $7,72 \mathrm{E}+11$ & 8,487358 & $9.099,00$ \\
\hline 2011 & $8,33 \mathrm{E}+11$ & 11,1135 & $16.182,00$ \\
\hline 2012 & $8,74 \mathrm{E}+11$ & 4,78992 & $13.744,00$ \\
\hline 2013 & $9,51 \mathrm{E}+11$ & 8,491316 & $13.563,00$ \\
\hline 2014 & $9,34 \mathrm{E}+11$ & 5,166672 & $13.119,00$ \\
\hline 2015 & $8,6 \mathrm{E}+11$ & 6,085899 & $18.002,00$ \\
\hline 2016 & $8,64 \mathrm{E}+11$ & 3,183819 & $13.343,00$ \\
\hline 2017 & $8,52 \mathrm{E}+11$ & 7,441233 & $10.922,00$ \\
\hline
\end{tabular}

Kaynak:www.world.bank.org (Erişim: 10.01.2019) 


\section{Ek-Çizelge 2: Türkiye'de Seçilmiş Yıllar İtibariyle 2006-2018 Döneminde Doğrudan Yabancı Sermayenin Yöneldiği Alanlar}

(Milyon US\$, \%)

\begin{tabular}{|l|l|l|l|l|l|l|}
\hline Üretim Kesimleri (Gözlem Değeri:Birikimli) & 2006 & $2006 /$ Pay $\%$ & 2010 & 2015 & 2018 & 2018 Pay \% \\
\hline TARIM SEKTÖRÜ & 6,00 & 0.03 & 81,00 & 31 & 43 & 0.79 \\
\hline SINAİ SEKTÖRLER & 2.988 & 16.93 & 2.887 & 5.774 & 2.391 & 43.97 \\
\hline Madencilik ve Taşocakçılı̆̆ & 123 & 0.70 & 136 & 207 & 165 & 3.03 \\
\hline İmalat Sanayi & 1.701 & 9.64 & 924 & 4.227 & 1.554 & 28.58 \\
\hline Gıda, İçecek ve Tütün Ürünleri İmalatı & 277 & 1.57 & 124 & 983 & 486 & 8.94 \\
\hline Ana Metal Sanayi & 194 & 1.10 & 213 & 100 & 46 & 0.85 \\
\hline Elektrik, Gaz,İklimlendirme & 1.164 & 6.60 & 1.824 & 1.338 & 668 & 12.29 \\
\hline Hi̇METLER KESiMİ & 14.645 & 83.02 & 3.288 & 6.272 & 3.004 & 55.24 \\
\hline Toptan ve Perakende Ticaret & 456 & 2.59 & 435 & 599 & 753 & 13.85 \\
\hline Ulaştırma ve Depolama & 453 & 2.57 & 183,00 & 1.524 & 385 & 7.08 \\
\hline Finans ve Sigorta Faaliyetleri & 6.954 & 39.42 & 1.621 & 3.516 & 951 & 17.49 \\
\hline Parasal Aracı Kurulușlar & 6.294 & 35.68 & 835 & 2.776 & 743 & 13.66 \\
\hline TOPLAM(Milyon ABD Doları) & 17.639 & 100,00 & 6.256 & 12.077 & 5.438 & 100.00 \\
\hline
\end{tabular}

Kaynak:www.tcmb.gov.tr, (Web erişim: 01.02.2019)

\section{Ek-Çizelge 3: Doğrudan yatırımların Kaynak Bölge-Ülke Dağılımı (2005-2018)}

(Milyon US Dolar)

\begin{tabular}{|l|l|l|l|l|l|l|l|l|l|l|l|l|l|}
\hline Tarih & Avrupa & Almanya & Avusturya & Hollanda & İniltere & İspanya & A.B.D. & Asya & Ortadoğu & Körfez & Azerbaycan & Toplam \\
\hline 2005 & 6.652 & 391 & 9 & 383 & 166 & 66 & 88 & 1.756 & 1.678 & 1.675 & 2 & & 8.535 \\
\hline 2006 & 14.574 & 357 & 1.108 & 5.069 & 628 & 53 & 848 & 1.927 & 1.910 & 1.783 & 1 & 17.639 \\
\hline 2007 & 12.974 & 954 & 370 & 5.442 & 703 & 583 & 4.212 & 1.405 & 608 & 311 & 10 & 19.137 \\
\hline 2008 & 11.368 & 1.237 & 586 & 1.343 & 1.335 & 838 & 868 & 2.345 & 2.184 & 1.963 & 18 & 14.748 \\
\hline 2009 & 5.248 & 497 & 1.019 & 717 & 350 & 145 & 260 & 673 & 361 & 209 & 69 & 6.266 \\
\hline 2010 & 4.939 & 597 & 1.584 & 486 & 245 & 205 & 323 & 928 & 473 & 388 & 12 & 6.256 \\
\hline 2011 & 12.587 & 664 & 2.419 & 1.424 & 906 & 2.251 & 1.401 & 2.056 & 1.559 & 196 & 1.266 & 16.136 \\
\hline 2012 & 7.927 & 491 & 1.519 & 1.381 & 2.044 & 193 & 439 & 2.337 & 1.593 & 940 & 338 & 10.761 \\
\hline 2013 & 7.057 & 1.970 & 667 & 918 & 300 & 581 & 326 & 2.899 & 2.286 & 880 & 803 & 10.523 \\
\hline 2014 & 6.370 & 606 & 31 & 2.022 & 1.051 & 74 & 334 & 1.886 & 1.336 & 364 & 884 & 8.632 \\
\hline 2015 & 7.983 & 355 & 80 & 1.184 & 585 & 2.305 & 1.619 & 2.464 & 1.317 & 460 & 839 & 12.077 \\
\hline 2016 & 4.850 & 440 & 345 & 1.024 & 974 & 318 & 338 & 2.246 & 1.358 & 540 & 661 & 7.534 \\
\hline 2017 & 4.927 & 312 & 320 & 1.727 & 328 & 1.460 & 180 & 1.701 & 1.260 & 252 & 1.005 & 7.401 \\
\hline 2018 & 3.549 & 320 & 449 & 607 & 394 & 178 & 366 & 1.445 & 858 & 341 & 503 & 5.438 \\
\hline
\end{tabular}

Kaynak:www.tcmb.gov.tr, (Web erişim: 01.02.2019) 